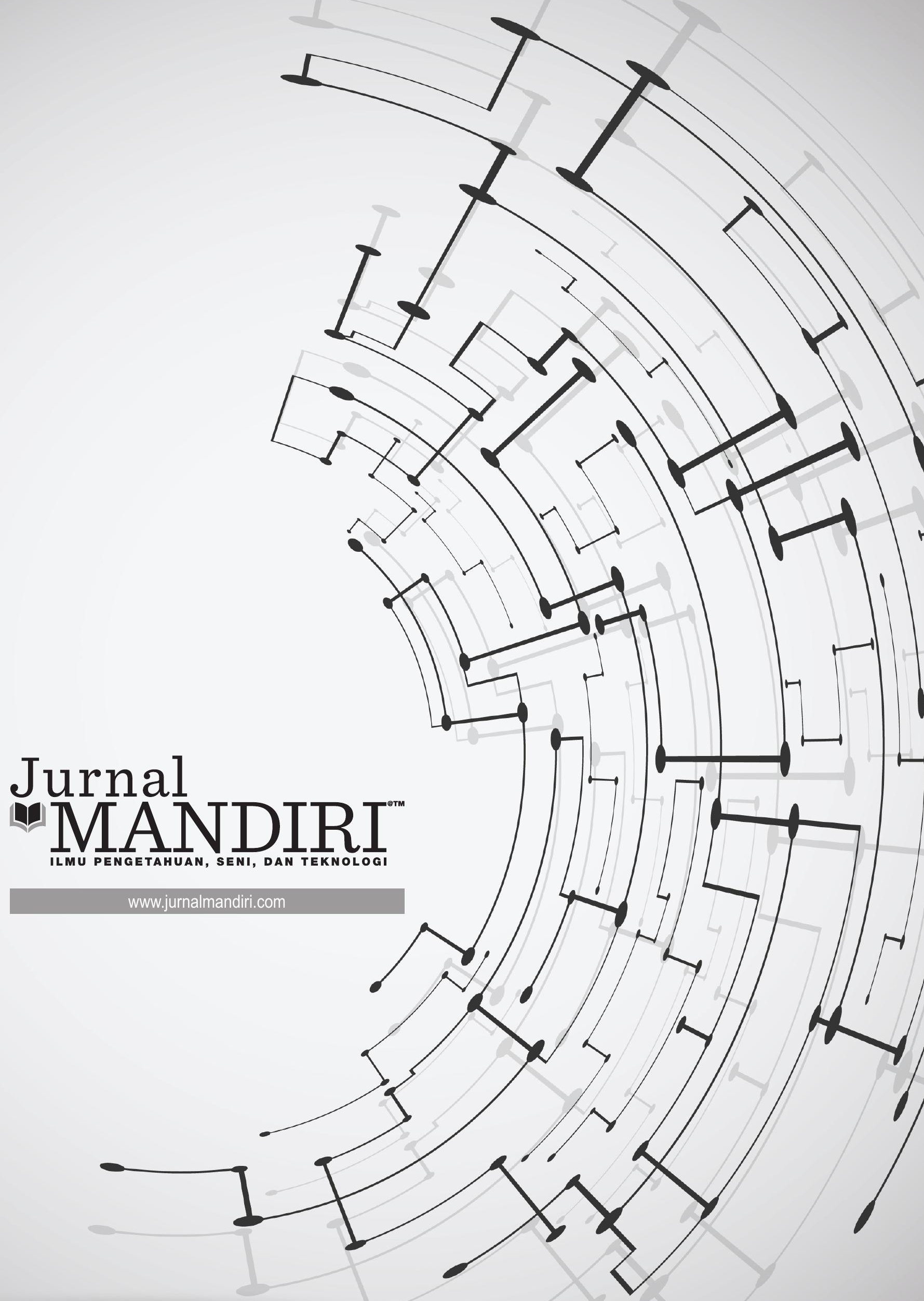


ISSN : 2580-3220, E-ISSN : 2580-4588

J. Mandiri., Vol. 4, No. 1, Juni 2020 (66 - 79)

(C)2018 Lembaga Kajian Demokrasi

dan Pemberdayaan Masyarakat (LKD-PM)

DOI : https://doi.org/10.33753/mandiri.v4i1.105

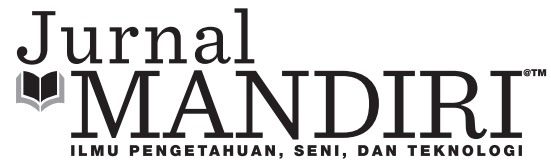

\title{
Pengaruh Brand Image Terhadap Keputusan Pembelian Pada Domino's Pizza Lippo Karawaci Utara
}

\author{
Ramon Hurdawaty \\ Program Studi Perhotelan, Politeknik Sahid \\ ramon.hurdawaty@polteksahid.ac.id \\ Ulfah Madaniyah \\ Program Studi Perhotelan, Politeknik Sahid \\ ulfahmdnyh20@gmail.com
}

\begin{abstract}
Abstrak
Tujuan Penelitian ini adalah untuk mengetahui pengaruh brand image terhadap keputusan pembelian pada Domino's Pizza Lippo Karawaci Utara dan untuk mengetahui besarnya pengaruh kedua variable tersebut. Penelitian ini menggunakan metode deskriptif kuantitatif dengan teknik survei. Teknik pengambilan sampel menggunakan teknik simple random sampling dengan jumlah sampel sebanyak 97 responden. Analisis data menggunakan alat bantu statistik dengan program SPSS versi 24 for windows dengan metode analisis uji validitas, reliabilitas, normalitas, koefisien korelasi, koefisien determinasi, persamaan regresi linier, dan uji hipotesis. Hasil analisis data menunjukkan persamaan regresi $Y=13,951+0,802 X$, dengan nilai koefisien korelasi sebesar 0,688 yang artinya variable brand image dengan keputusan pembelian mempunyai hubungan yang kuat. Hasil analisis hipotesis (uji $t)$ diperoleh nilai $t_{\text {hitung }}$ lebih besar dari $t_{\text {table }}(9,239>1,98525)$ dengan signifikan 0,000. Kontribusi pengaruh brand image terhadap keputusan pembelian adalah sebesar 47,3\% ( $R$ square $=0,473)$, dan sisanya 52,7\% dipengaruhi oleh variable lain diluar variable yang diuji, seperti loyalitas pelanggan, kualitas pelayanan, dan lain-lain. Sehingga dapat disimpulkan bahwa brand image memiliki pengaruh yang positif dan signifikan terhadap keputusan pembelian.
\end{abstract}

Kata Kunci : Citra Merek, Keputusan Pembelian, Kuantitatif

\begin{abstract}
The purpose of this study was to determine the effect of brand image on purchasing decisions on Domino's North Lippo Karawaci Pizza and to determine the effect of these two variables. This research uses quantitative descriptive methods with survey techniques. The sampling technique uses simple random sampling technique with a sample size of 97 respondents. Data analysis using statistical tools with SPSS version 24 for windows with the analysis method of validity, reliability, normality, distribution coefficient, determination coefficient, linear regression equation, and hypothesis testing. The results of data analysis showed a regression equation $Y$ $=13,951+0.802 X$, with a value of the consideration coefficient of 0.688 which means that the brand image variable with a purchasing decision has a strong relationship. The results of hypothesis analysis (ttest) obtained $t_{\text {value }}$ greater than $t_{\text {table }}(9.239>1.98525)$ with a significant 0.000 . The contribution of brand image influence on purchasing decisions amounted to $47.3 \%(R$ square $=0.473$ ), and the remaining $52.7 \%$ is needed by other variables that exceed the contested variables, such as customer loyalty, service quality, and others. Brand image can have a positive and significant influence on purchasing decisions.
\end{abstract}

Keywords : Brand Image, Purchasing Decision, Quantitative 


\section{PENDAHULUAN}

Bisnis kuliner merupakan sektor industri yang saat ini mengalami kemajuan. Hal ini terjadi karena kebutuhan fisiologis setiap konsumen meningkat salah satunya kebutuhan akan makanan dan minuman. Kenyataan ini merupakan peluang yang dimanfaatkan setiap pengusaha restoran untuk membuka usaha kuliner dengan menghadirkan menu yang unik dan memberikan berbagai macam promosi sehingga dapat menarik minat beli konsumen.

Bisnis fast-food merupakan usaha kuliner yang mengalami perkembangan pesat, sebagai contoh adalah bisnis restoran pizza. Pizza merupakan jenis makanan siap saji. Pizza merupakan makanan siap saji yang sangat populer di Indonesia, sehingga makin besar peluang mendirikan kedai Pizza. Saat ini restoran Pizza yang ada di Indonesia antara lain Pizza Hut, Domino's Pizza, Papa Ron's, Gian Pizza, dan Pizza Bar. Dengan semakin banyak restoran Pizza di Indonesia menyebabkan semakin ketatnya persaingan bisnis dalam mendapatkan pelanggan.

Kota Tangerang terdapat cukup banyak restoran pizza dengan persaingan cukup ketat, seperti Pizza e Birra, Henk's Pizza, Popolamama, Pizza Marzano, Panties Pizza, Domino's Pizza, Pizza Hut, Papa Ron's Pizza, Pezzo Pizza, PHD. Hal ini menuntut agar perusahaan dapat mempertahankan pelanggannya agar tidak berpindah ke pesaing. Dalam memilih produk yang diminati, konsumen sangatlah kritis. Saat ini restoran sejenis banyak menawarkan produk dengan berbagai macam promosi untuk produknya. Semakin banyaknya alternatif produk, semakin memudahkan konsumen dalam memilih produk sesuai minat dan kesanggupan ekonomi. Oleh karena itu, tampilan dan citarasa produk harus memiliki ciri khas, agar konsumen dapat terus membeli produk tersebut. Keputusan pembelian suatu produk khususnya produk makanan sangat dipengaruhi persepsi konsumen terhadap kualitas produk tersebut, sehingga perusahaan berlombalomba untuk meningkatkan kualitas produknya dengan tetap mempertahankan brand image (citra merek) yang dimiliki.

Schiffman dan Kanuk (2007) menjelaskan bahwa "Keputusan pembelian adalah pemilihan dari dua atau lebih alternatif pilihan yang ada, artinya bahwa syarat seseorang dapat membuat keputusan haruslah tersedia beberapa alternatif lainnya".

Brand image menurut Surachman (2008) adalah sebagai bagian dari brand yang dapat dikenali namun tidak dapat diucapkan, seperti lambang, desain huruf atau warna khusus, atau persepsi pelanggan atas sebuah produk atau jasa yang diwakili oleh brandnya. Setiap perusahaan berusaha untuk mempertahankan brand image yang dimilikinya seperti dengan menerapkan inovasi teknologi brand tersebut. Dengan semakin baiknya brand image produk yang dijual, menyebabkan semakin meningkatnya keputusan pembelian konsumen.

Domino's Pizza adalah brand restoran dengan menyediakan pizza sebagi menu utamanya. Domino's Pizza dikenal sebagai "The Pizza Delivery Experts" karna mereka menyediakan jasa pesan antar dengan janji servis pengantaran pizza kurang dari 30 menit, jika lebih dari 30 menit akan mendapatkan pizza gratis. Domino's pizza juga menyediakan banyak promosi agar menarik minat konsumen untuk memebeli, salah satunya adalah hanya dengan membayar Rp110.000.konsumen akan mendapatkan 2 medium pizza dengan pilihan rasa yang berbeda. Hal yang membuat Domino's pizza berbeda dengan produk lainnya adalah dengan adanya pizza dengan roti yang tipis dan renyah. Dari segi variasi produk Domino's pizza selalu melakukan inovasi-inovasi baru yang sesuai dengan keinginan konsumen. Sehingga adanya brand image Domino's Pizza, menyebabkan konsumen tertarik melakukan pembelian produk tersebut.

Target konsumen Domino's Pizza adalah semua kalangan. Domino's Pizza mencitrakan diri sebagai restoran cepat saji yang menyediakan layanan pesan antar dengan waktu kurang dari 30 menit dengan garansi pizza gratis. Hal ini membuat masyarakat berkeinginan untuk membeli produk Domino's Pizza. Namun restoran cepat saji yang menyediakan pizza bukan hanya Domino's Pizza, terdapat beberapa restoran yang menyajikan menu utama yang sama. Membuat 
mereka berlomba-lomba menanamkan citra positif dimata konsumen, karena citra positif yang dimiliki konsumen terhadap merek produk akan menyebabkan konsumen melakukan pembelian kembali (repurchase).

Domino's Pizza memiliki TBI (Top Brand Index) dengan urutan kedua dengan presentase lebih rendah dibandingkan dengan Pizza Hut yang hadir lebih dulu di Indonesia. Menurut Top Brand Awards 2018, pengukuran TBI dilakukan dengan tiga parameter yaitu top of mind awareness (merek yang ada di benak konsumen pertama kali), last used (merek yang terakhir digunakan), dan future intention sampling (merek yang ingin digunakan untuk pemakaian selanjutnya). Ketiga parameter tersebut membuktikan bahwa Domino's Pizza masih belum membentuk citra merek yang kuat dibandingkan dengan pesaingnya yaitu Pizza Hut, sehingga mereknya masih menjadi second of mind di benak konsumen.

Domino's Pizza mememilki banyak cabang di Indonesia yang terbagi di beberapa kota-kota besar. Terdapat kurang lebih 10 cabang yang berada di daerah Tangerang, salah satu cabang yang akan digunakan untuk penelitian adalah Domino's Pizza Lippo Karawaci Utara. Grafik 1 adalah data mengenai jumlah pembeli yang datang ke Domino’s Pizza Lippo Karawaci Utara:

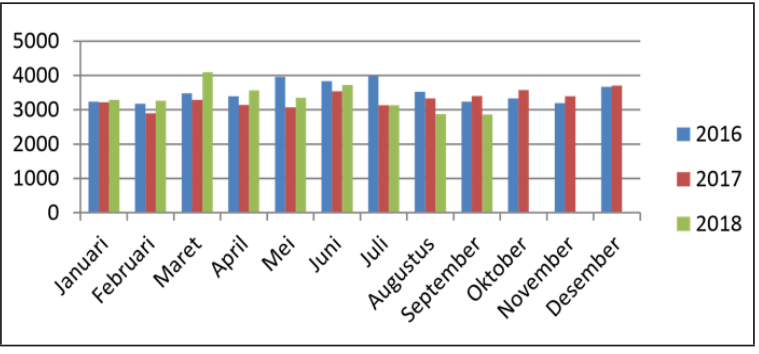

Grafik 1. Grafik Jumlah Transaksi Pembelian Domino's Pizza Lippo Karawaci Utara Tahun 2016-2018

Sumber: Domino's Pizza Lippo Karawaci Utara, 2018

Dari grafik 1 menunjukkan transaksi pembelian produk Domino's Pizza Lippo Karawaci Utara mempunyai pola yang fluktuatif setiap bulannya, hal ini mungkin terjadi karena promo yang ditawarkan masing-masing bulan selalu berbeda. Jika dibandingkan setiap bulannya antara tahun 2016 sampai dengan tahun 2018 tingkat jumlah transaksi pembelian tidak stabil, kadang meningkat dan kadang selalu menurun. Contohnya pada beberapa bulan yaitu Januari, Februari, Maret dan april memiliki jumlah transaksi pembelian yang meningkat.

Keadaan ini menyebabkan manajemen selalu berusaha untuk meningkatkan inovasi, baik dari segi variasi menu, promosi, serta pelayanan agar berhasil dalam menarik minat konsumen dan mempertahankan pelanggan. Salah satu upaya dari Domino's Pizza Lippo Karawaci Utara adalah meningkatkan brand image dimata konsumen.

Dari penjelasan yang telah dikemukan di atas, penulis tertarik untuk melakukan penelitian mengenai pengaruh brand image terhadap keputusan pembelian di Domino's Pizza Lippo Karawaci Utara. Adapun tujuan penelitian ini adalah untuk mengetahui adanya pengaruh brand image terhadap keputusan pembelian serta mengetahui besarnya pengaruh tersebut.

\section{METODE}

Penelitian ini menggunakan metode penelitian kuantitatif dengan metode deskriptif yaitu metode penelitian yang bermaksud untuk mendeksripsikan fakta-fakta yang ada yang terjadi pada saat ini atau kejadian lampau. Studi ini tidak mendeskripsikan suatu keadaan apa adanya. Penggambaran kondisi bisa individual atau kelompok, dan menggunakan angka-angka (Hamdi, 2014). Unit analisis yang gunakan dalam metode penelitian ini adalah konsumen Domino's Pizza Lippo Karawaci Utara.

Definisioperasional dalam variabel penelitian adalah pemaparan terhadap indikator dari masing-masing variabel yang digunakan. Brand image adalah sebagai variable independent, dan keputusan pembelian sebagai variable dependen. Brand image (X) adalah salah satu elemen paling penting yang ditimbulkan oleh suatu brand dalam benak pelanggan. Keputusan pembelian $(\mathrm{Y})$ adalah pemilihan dari dua atau lebih alternatif pilihan yang ada. Berikut dijelaskan pada Tabel 1 mengenai definisi operasional variable yang digunakan dalam penelitian ini. 


\begin{tabular}{|c|c|c|c|c|}
\hline \multicolumn{5}{|c|}{ Tabel 1. Definisi Operasional Variabel } \\
\hline No & Variabel & Sub Variabel & Indikator & $\begin{array}{c}\text { Nomor } \\
\text { Butir }\end{array}$ \\
\hline \multirow{6}{*}{1} & \multirow{6}{*}{$\begin{array}{l}\text { Brand Image } \\
\text { (X) } \\
\text { (Simamora, } \\
\text { 2011) }\end{array}$} & \multirow{2}{*}{$\begin{array}{l}\text { 1. Citra Pembuat } \\
\text { (Corporate } \\
\text { Image) }\end{array}$} & Popularitas & 1,2 \\
\hline & & & Kredibilitas & $3,4,5$ \\
\hline & & \multirow{3}{*}{$\begin{array}{l}\text { 2. Citra Produk } \\
\text { (Product } \\
\text { Image) }\end{array}$} & Atribut produk & 6,7 \\
\hline & & & Jaminan & 8,9 \\
\hline & & & $\begin{array}{l}\text { Manfaat bagi } \\
\text { konsumen }\end{array}$ & 10 \\
\hline & & $\begin{array}{l}\text { 3. Citra Pemakai } \\
\text { (User Image) }\end{array}$ & $\begin{array}{l}\text { Konsumen itu } \\
\text { sendiri }\end{array}$ & $\begin{array}{l}11,12 \\
13,14\end{array}$ \\
\hline \multirow{13}{*}{2} & \multirow{13}{*}{$\begin{array}{l}\text { Keputusan } \\
\text { Pembelian } \\
\text { (Kotler dan } \\
\text { Amstrong, } \\
\text { 2008) }\end{array}$} & \multirow{2}{*}{$\begin{array}{l}\text { 1. Pengenaan } \\
\text { Kebutuhan }\end{array}$} & $\begin{array}{l}\text { Rangsangan } \\
\text { Internal }\end{array}$ & 1,2 \\
\hline & & & $\begin{array}{l}\text { Rangsangan } \\
\text { Eksternal }\end{array}$ & 3 \\
\hline & & \multirow{3}{*}{$\begin{array}{l}\text { 2. Pencarian } \\
\text { Informasi }\end{array}$} & Melalui kerabat & 4 \\
\hline & & & Melalui media sosial & 5 \\
\hline & & & Melalui internet & 6 \\
\hline & & \multirow{2}{*}{$\begin{array}{l}\text { 3. Evaluasi } \\
\text { Alternatif }\end{array}$} & Keyakinan & 7 \\
\hline & & & Sikap & 8,9 \\
\hline & & \multirow{3}{*}{$\begin{array}{l}\text { 4. Keputusan } \\
\text { Pembelian }\end{array}$} & Rasa & 10 \\
\hline & & & Harga & 11 \\
\hline & & & Sesuai Kebutuhan & 12 \\
\hline & & \multirow{3}{*}{$\begin{array}{l}\text { 5. Perilaku Pasca } \\
\text { Pembelian }\end{array}$} & Kepuasan & 13 \\
\hline & & & Merekomendasikan & 14 \\
\hline & & & Membeli Kembali & 15 \\
\hline
\end{tabular}

Populasi yang digunakan dalam penelitian ini merupakan jumlah transaksi pembelian mulai dari awal hingga akhir bulan September 2018 sebanyak 2862 orang. Teknik penentuan sampel yang digunakan adalah teknik Simple Random Sampling yang merupakan proses memilih satuan sampel dari populasi sedemikian rupa sehingga setiap satuan sampel dalam populasi mempunyai peluang yang sama besar untuk terpilih ke dalam sampel, dan peluang tersebut diketahui sebelum pemilihan dilakukan (Sedarmayanti dan Hidayat, 2011). Untuk menentukan sampel dari suatu populasi peneliti menggunakan rumus Slovin :

$$
n=\frac{N}{1+N(e)^{2}}
$$

Keterangan :

$\mathrm{n}$ : Jumlah Sampel

$\mathrm{N}$ : Jumlah Populasi

e : Margin of Eror Maximum, yaitu penyimpangan dengan batas maksimum yang masih dapat ditolerir $(\mathrm{e}=10 \%)$

$$
\begin{aligned}
& \mathrm{n}=\frac{2.862}{1+2.862(0.1)^{2}} \\
& =\frac{2.862}{1+2.862(0,01)} \\
& =96,62 \mathrm{n}=97
\end{aligned}
$$

Berdasarkan perhitungan diatas, banyaknya sampel yang digunakan adalah 97 orang.

Jenis data untuk menyusun proyek akhir ini ada 2, yaitu :

- Data Primer adalah data lapangan yang secara langsung peneliti kumpulkan dari tempat objek penelitian yang menggunakan hasl kuesioner dari pengunjung Domino's Pizza Lippo Karawaci Utara/

- Data Sekunder merupakan data baku penelitian yang dikumpulkan melalui pihak kedua, seperti data yang berasal dari Domino's Pizza Lippo Karawaci Utara, sumber pustaka seperti buku, website dan jurnal penelitian yang berkaitan.

Teknik analisis data dalam penelitian ini menggunakan cara kuantitatif dengan terlebih dahulu menguji validitas dan reliabilitas kedua variable, pengujian normalitas, dan uji t untuk mengetahui pengaruh (regresi) variable bebas (independent variable) terhadap variable terikat (dependent variable), dengan menggunakan Program SPSS for Windows untuk analisis data.

\section{Uji Validitas dan Reliabilitas}

\section{Uji Validitas}

Uji validitas dalam penelitian bertujuan untuk mengukur sah (valid) atau tidaknya kuesioner yang digunakan. Kuesioner yang sah (valid) memiliki pertanyaan yang dapat menyatakan sesuatu yang akan diukur oleh kuesioner tersebut. Penentuan hasil Uji validitas dengan cara membandingkan nilai $\mathrm{r}_{\text {hitung }}$ (dilihat pada kolom corrected item-total correlations) dengan $\mathrm{r}_{\text {tabel }}$, degree of freedom $(\mathrm{df})=\mathrm{n}-\mathrm{k}, \mathrm{n}$ merupakan jumlah sampel dan k merupakan jumlah item pertanyaan. 
Jika $\mathrm{r}_{\text {hitung }}>\mathrm{r}_{\text {tabep }}$ maka pertanyaan pada kuesioner tersebut adalah valid (Ghozali, 2011).

$$
r_{x y}=\frac{n \sum x y-\sum x \sum y}{\sqrt{\left.\ln \sum x^{2}-\left(\sum x\right)^{2}\right)\left(n \sum y^{2}-\left(\sum y\right)^{2}\right)}}
$$

Dimana :

$\mathrm{rxy}=$ koefisien korelasi ( $\mathrm{r}$ hitung)

$\Sigma \mathrm{x}=$ Skor variabel independen

$\Sigma y=$ Skor variabel dependen

$\sum x y=$ Jumlah dari hasil perkalian xy

$\mathrm{n}=$ Jumlah responden yang digunakan

\section{Uji Reliabilitas}

Uji reliabilitas berfungsi untuk mengukur kehandalan kuisioner penelitian. Kuisioner yang reliabel atau handal adalah dimana masingmasing pertanyaan dijawab responden secara konsisten atau stabil dari waktu ke waktu. Pengukuran reliabilitas menggunakan SPSS dengan uji statistik Cronbach Alpha (a). Variabel penelitian yang reliabel adalah dengan nilai $\alpha>0,60$ (Ghozali, 2011).

\section{Uji Normalitas}

Uji normalitas berfungsi untuk mengetahui apakah variabel dependen dan variabel independen memiliki distribusi normal atau tidak dalam sebuah model regresi. Model regresi yang baik adalah yang berdistribusi normal atau mendekati normal. Uji normalitas menggunakan uji One Sample Kolmogorof-Smirnov.

Dasar pengambilan keputusan adalah sebagai berikut:

- Data berdistribusi normal, jika nilai sig (signifikansi) > 0,05.

- Data tidak berdistribusi normal, jika nilai sig (signifikansi) $<0,05$.

\section{Uji Koefisien Korelasi}

Uji koefisien korelasi digunakan untuk mengetahui tingkat hubungan antara variabel dependen dan independen yang ditunjukkan dengan koefisien korelasi. Teknik statistik yang digunakan korelasi Pearson Product Moment dengan rumus sebagai berikut:

$$
r_{x y}=\frac{n \Sigma x_{i} y_{i}-\left(\Sigma x_{i}\right)\left(\Sigma y_{i}\right)}{\sqrt{\left.\sqrt{\{n \Sigma} x_{i}^{2}-\left(\Sigma x_{i}\right)^{2}\right\}-\left\{n \Sigma y_{i}^{2}-\left(\Sigma y_{i}\right)^{2}\right.}}
$$

Keterangan :

$\mathrm{r}=$ koefisien korelasi pearson

$\mathrm{x}=$ variabel independen

$\mathrm{y}=$ variabel dependen

$\mathrm{n}$ = banyak sampel

Koefisien korelasi yang diperoleh dari rumus diatas dinterpterasikan dengan mengacu pada

\begin{tabular}{|c|c|c|}
\hline \multicolumn{3}{|c|}{ Tabel 2. Pedoman Menginterpretasikan Koefisien Korelasi } \\
\hline No & Interval Koefisien & Tingkat Hubungan \\
\hline 1 & $0,00-0,199$ & Sangat Rendah \\
\hline 2 & $0,20-0,399$ & Rendah \\
\hline 3 & $0,40-0,599$ & Sedang \\
\hline 4 & $0,50-0,799$ & Kuat \\
\hline 5 & $0,80-1,000$ & Sangat Kuat \\
\hline \multicolumn{3}{|c|}{ Sumber : Sugiyono (2014 } \\
\hline
\end{tabular}
Tabel 2 berikut :

Hasil perhitungan koefisien korelasi kemudian dibandingkan dengan $\mathrm{r}_{\text {tabel }}$ dengan taraf signifikansi 0,05 untuk mengetahui terdapat hubungan yang signifikan atau tidak. Jika $\mathrm{r}_{\text {hitung }}>$ $\mathrm{r}_{\text {tabel }}$ maka $\mathrm{H}_{0}$ ditolak artinya terdapat hubungan yang signifikan, jika $\mathrm{r}_{\text {hitung }}<\mathrm{r}_{\text {tabel }}$ maka $\mathrm{H}_{0}$ diterima artinya tidak terdapat hubungan signifikan antara variabel bebas dan terikat.

\section{Koefisien Determinasi $\left(\mathbf{R}^{2}\right)$}

Koefisien determinasi $\left(\mathrm{R}^{2}\right)$ digunakan untuk mengetahui besarnya (persentase) perubahan variabel terikat $(\mathrm{Y})$ yang dipengaruhi variabel bebas (X).

\section{Analisis Regresi Linier Sederhana}

Analisis regresi linier sederhana berfungsi untuk menganalisis pengaruh brand image terhadap keputusan pembelian di Domino's Pizza Lippo Karawaci Utara. Model persamaan garis yang menunjukkan hubungan antar dua variabel adalah sebagai berikut :

$\mathrm{Y}=\mathrm{a}+\mathrm{bY}$

keterangan :

$\mathrm{Y}=$ Variabel dependen/terikat

$\mathrm{X}=$ Variabel independen/bebas

$\mathrm{a}=$ Bagian konstanta/intersep

$\mathrm{b}=$ Koefisien arah regresi/slope

\section{Uji Hipotesis (Uji t)}

Uji t digunakan untuk menguji secara parsial 
signifikansi hubungan antar variabel $\mathrm{X}$ dan $\mathrm{Y}$, dalam penelitian ini apakah variabel brand image memiliki pengaruh terhadap variabel keputusan pembelian.

Kriteria pengujian hipotesis sebagai berikut:

- Jika $\mathrm{t}_{\text {hitung }}>$ nilai $\mathrm{t}_{\text {tabel }}$ maka Hipotesis $\mathrm{H}_{0}$ ditolak dan $\mathrm{H}_{1}$ diterima

- Jika $\mathrm{t}_{\text {hitung }}<$ nilai $\mathrm{t}_{\text {tabel }}$ maka Hipoteisi $\mathrm{H}_{0}$ diterima dan $\mathrm{H}_{1}$ ditolak

Hipotesis $\mathrm{H}_{0}$ diterima, artinya secara parsial tidak terdapat pengaruh brand image terhadap keputusan pembelian. Jika $\mathrm{H}_{0}$ ditolak, artinya ada pengaruh yang signifikan brand image terhadap keputusan pembelian.

\section{HASIL dan PEMBAHASAN}

\section{Hasil}

\section{Brand Image}

Menurut Suyanto (2007) "Merek merupakan kombinasi dari nama, kata, simbol, atau desain yang memberi identitas produk". Aaker (2010) mengungkapkan bahwa "Brand adalah aset menciptakan value bagi pelanggan dengan meningkatkan kepuasan dan menghargai kualitas". Sedangkan Kotler dan Armstrong (2008) menyatakan "Merek adalah nama, istilah, tanda, lambang, desain atau kombinasi dari hal-hal tersebut yang dimaksudkan untuk mengidentifikasi barang atau jasa dari seseorang atau sekelompok penjual untuk membedakannya dari produk atau barang pesaing".

Surachman (2008) menjelaskan "Brand image sebagai bagian dari brand yang dapat dikenali namun tidak dapat diucapkan, seperti lambang, desain huruf atau warna khusus, atau presepsi pelanggan atas sebuah produk atau jasa yang diwakili oleh brandnya. Dapat juga dikatakan bahwa brand image merupakan konsep yang diciptakan oleh konsumen karena alasan subyektif dan emosi pribadinya".

Menurut Simamora (2011) komponen brand image terdiri atas tiga bagian, yaitu :

a. Citra Pembuat (Corporate Image)

Yaitu sekumpulan asosiasi yang dipresepsikan konsumen terhadap perusahaan yang membuat suatu produk atau jasa. Corporate image meliputi: popularitas, kredibilitas, serta jaringan perusahaan.

b. Citra Pemakai (User Image)

Yaitu sekumpulan asosiasi yang dipresepsikan konsumen terhadap pemakai yang menggunakan suatu barang atau jasa. Meliputi: pemakai itu sendiri, gaya hidup/kepribadian, serta status sosialnya.

c. Citra Produk (Product Image)

Yaitu sekumpulan asosiasi yang dipresepsikan konsumen terhadap suatu produk. Meliputi atribut produk tersebut, manfaat bagi konsumen penggunanya, serta jaminan.

Menurut Schiffman dan Kanuk (2007) menyebutkan faktor-faktor pembentuk brand image adalah sebagai berikut:

a. Kualitas atau mutu, berkaitan dengan kualitas produk yang ditawarkan oleh produsen dengan merek tertentu.

b. Dapat dipercaya atau diandalkan, berkaitan dengan pendapat dan kesepakatan yang di bentuk oleh masyarakat tentang suatu produk yang dikonsumsi.

c. Kegunaan atau manfaat, yang terkait dengan fungsi dari suatu produk yang bisa dimanfaatkan oleh konsumen.

d. Pelayanan, yang berkaitan dengan tugas produsen dalam melayani konsumennya.

e. Resiko berkaitan dengan untung rugi yang dialami oleh konsumen.

f. Harga, dalam hal ini berkaitan dengan tinggi rendahnya atau banyak sedikitnya jumlah uang yang dikeluarkan konsumen untuk mempengaruhi suatu produk, juga dapat mempengaruhi citra jangka panjang.

g. Image, yang dimiliki merek itu sendiri, yaitu berupa pelanggan, kesempatan dan informasi yang berkaitan dengan suatu merek dari produk tertentu.

Dari teori yang sudah dijelaskan dapat disimpulkan brand image adalah persepsi yang timbul disebabkan oleh suatu brand dalam benak pelanggan. Brand image dalam benak pelanggan harus dilakukan berkesinambungan agar brand image yang dihasilkan konsisten, kuat dan secara positif diterima konsumen. Brand yang memiliki image kuat dan positif di benak konsumen akan 
terus menerus diingat dan konsumen akan selalu membeli produk dari brand tersebut.

\section{Keputusan Pembelian}

Schiffman dan Kanuk (2007) menjelaskan "Keputusan pembelian adalah pemilihan dari dua atau lebih alternatif pilihan yang ada, artinya bahwa syarat seseorang dapat membuat keputusan haruslah tersedia beberapa alternatif lainnya".

Menurut Kotler dan Amstrong (2012) faktorfaktor keputusan pembelian terdiri dari:

a. Faktor Kebudayaan

Faktor kebudayaan berpengaruh luas dan mendalam terhadap perilaku konsumen. Faktor kebudayaan tediri dari: budaya, subbudaya, dan kelas sosial.

b. Faktor Sosial

Selain faktor budaya, perilaku konsumen juga dipengaruhi oleh faktor-faktor sosial seperti kelompok acuan, keluarga serta status sosial.

c. Faktor Pribadi

Faktor pribadi yang memberikan kontribusi terhadap perilaku konsumen terdiri dari usia dan tahap siklus hidup, pekerjaan dan lingkungan ekonomi, gaya hidup kepribadian dan konsep diri.

d. Faktor Psikologis

Pilihan pembelian seseorang dipengaruhi oleh empat faktor psikologis utama yaitu motivasi, persepsi, pembelajaran, serta keyakinan dan pendirian.

Menurut Kotler dan Amstrong (2008), proses keputusan pembelian terdiri dari lima tahap yaitu: pengenalan kebutuhan, pencarian informasi, evaluasi alternatif, keputusan pembelian, dan perilaku pasca pembelian.

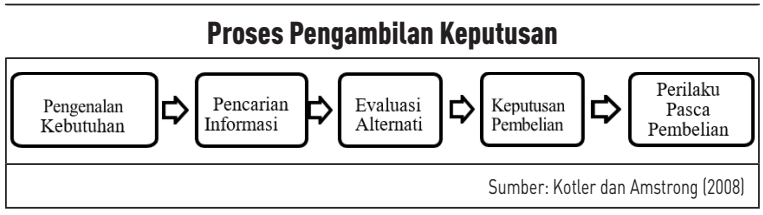

Berikut dijelaskan tahapan proses pengambilan keputusan :

\section{- Pengenalan Kebutuhan}

(Problem Recognition)

Proses pembelian oleh konsumen diawali sejak pembeli mengenali kebutuhan atau masalah. Kebutuhan tersebut dapat ditimbulkan oleh rangsangan internal atau eksternal. Rangsangan internal, terjadi pada salah satu kebutuhan umum seseorang (seperti lapar dan haus) telah mencapai ambang batas tertentu dan mulai menjadi pendorong. Sedangkan rangsangan eksternal, salah satunya terjadi karena seseorang menonton iklan atau melihat produk baru milik tetangganya.

- Pencarian Informasi (Information Search) Setelah konsumen yang terangsang kebutuhannya, konsumen akan terdorong untuk mencari informasi yang lebih banyak. Orang lebih peka terhadap informasi produk. Selanjutnya, orang mulai aktif mencari informasi : bertanya kepada teman, mendatangi toko untuk mecari tahu atau membuka-buka internet untuk membandingkan spesifikasi dan harga barang.

- Evaluasi Alternatif

\section{(Evaluation of Alternatives)}

Evaluasi umumnya mencerminkan keyakinan dan sikap yang mempengaruhi perilaku pembelian mereka. Keyakinan (believe) adalah gambaran pemikiran yang dianut seseorang tentang gambaran sesuatu. Keyakinan seseorang tentang produk atau brand mempengaruhi keputusan pembelian mereka. Yang tak kalah pentingnya dengan keyakinan adalah sikap. Sikap (attitude) adalah evaluasi, perasaan emosi, dan kecenderungan tindakan yang menguntungkan atau tidak menguntungkan dan bertahan lama pada seseorang pada objek atau gagasan tertentu.

\section{- Keputusan Pembelian (Purchase Decioson)}

Dalam suatu kasus pembelian, kosumen bisa mengambil beberapa sub keputusan, meliputi merek, pemasok, jumlah, waktu pelaksanaan dan metode pembayaran. Contohnya ketika membeli kendaraan atau peralatan mesin. Namun dalam pembelian produk seharihari, keputusan konsumen bisa jadi lebih sederhana. Contohnya ketika membeli gula, seorang konsumen tidak banyak berpikir tentang pemasok atau metode pembayaran.

\section{- Perilaku Pasca Pembelian}




\section{(Postpurchase Behavior)}

Setelah pembelian dilakukan, konsumen akan selalu siaga terhadap informasi yang mendukung keputusannya. Konsumen akan membandingkan produk yang telah ia beli, dengan produk lain. Hal ini dikarenakan konsumen mengalami ketidakcocokan dengan fasilitas-fasilitas tertentu pada barang yang telah ia beli, atau mendengar keunggulan tentang merek lain.

\section{Hasil Analisis Kuisioner}

Profil Responden Menurut Jenis Kelamin

\begin{tabular}{|c|c|c|}
\hline \multirow{2}{*}{ Tabel 3. Profil Responden Berdasarkan Jenis Kelamin } \\
\hline \multirow{2}{*}{ Jenis Kelamin } & \multicolumn{2}{|c|}{ Jumlah } \\
\cline { 2 - 3 } & Frekuensi & Presentase (\%) \\
\hline Pria & 45 & 46,39 \\
\hline Wanita & 52 & 53,61 \\
\hline Total & 97 & 100 \\
\hline
\end{tabular}

Tabel 3 terlihat bahwa jumlah responden berdasarkan jenis kelamin dengan presentase yang paling tinggi adalah wanita dengan jumlah 52 orang $(53,61 \%)$, sedangkan responden pria berjumlah 45 orang $(46,39 \%)$. Dari data tersebut diketahui bahwa responden wanita lebih aktif daripada pria, hal tersebut juga menunjukkan konsumen yang datang lebih banyak wanita.

\section{Profil Responden Menurut Usia}

\begin{tabular}{|c|c|c|}
\hline \multicolumn{3}{|c|}{ Tabel 4. Profil Responden Berdasarkan Usia } \\
\hline \multirow{2}{*}{ Tingkat Usia } & \multicolumn{2}{|c|}{ Jumlah } \\
\hline & Frekuensi & Presentase $[\%]$ \\
\hline $17-27$ tahun & 33 & 34,02 \\
\hline $28-38$ tahun & 37 & 38,14 \\
\hline $39-49$ tahun & 24 & 24,74 \\
\hline 50-59 tahun & 3 & 3,10 \\
\hline$>60$ tahun & - & - \\
\hline Total & 97 & 100 \\
\hline
\end{tabular}

Berdasarkan tabel 4 dapat diketahui bahwa umur responden yang terbanyak adalah yang berumur 28-38 tahun yaitu sebanyak 37 orang $(38,14 \%)$, diikuti dengan usia responden 17-27 tahun yaitu sebanyak 33 orang (34,02\%). Hal ini disebabkan karena pada umur tersebut biasanya seseorang memiliki keinginan untuk meluangkan waktunya bersama keluarga maupun teman dengan mengunjungi restoran untuk makan bersama.

\section{Frekuensi Kunjungan Responden}

Tabel 5. Frekuensi Kunjungan Responden Dalam 1 Tahun Terakhir

\begin{tabular}{|c|c|c|}
\multirow{2}{*}{ Tingkat Usia } & \multicolumn{2}{|c|}{ Jumlah } \\
\cline { 2 - 3 } & Frekuensi & Presentase $(\%)$ \\
\hline 1 kali & 12 & 12,37 \\
\hline 2-5 kali & 33 & 34,02 \\
\hline 5-10 kali & 34 & 35,05 \\
\hline >10 kali & 18 & 18,56 \\
\hline Total & 97 & 100 \\
\hline
\end{tabular}

Tabel 5 menunjukkan bahwa responden paling banyak yang sudah berkunjung ke Domino's Pizza Lippo Karawaci Utara hingga 5-10 kali yaitu sebanyak 34 orang (35.05\%), kemudian diikuti responden yang berkunjung 2-5 kali yaitu 33 orang $(34,02 \%)$. Data tersebut menunjukkan bahwa penelitian ini menggunakan responden yang sudah sering berkunjung ke Domino's Pizza Lippo Karawaci Utara.

\section{Profil Responden Menurut Pekerjaan}

\begin{tabular}{|c|c|c|}
\hline \multirow{2}{*}{ Tabel 6. Profil Responden Menurut Pekerjaan } \\
\cline { 2 - 3 } Tingkat Usia & \multicolumn{2}{|c|}{ Jumlah } \\
\cline { 2 - 3 } & Frekuensi & Presentase (\%) \\
\hline Pegawai Negeri Sipil (PNS) & 3 & 3,09 \\
\hline Pegawai Swasta & 27 & 27,84 \\
\hline Wirausaha & 8 & 8,25 \\
\hline Ibu Rumah Tangga & 25 & 25,77 \\
\hline Pelajar/Mahasiswa & 21 & 21,65 \\
\hline Lainnya & 13 & 13,40 \\
\hline Total & 97 & 100 \\
\hline
\end{tabular}

Tabel 6 menunjukkan bahwa pekerjaan sebagian responden adalah sebagai pegawai swasta yaitu sebanyak 27 orang (28\%), diikuti oleh responden yang bekerja sebagai ibu rumah tangga yaitu sebanyak 25 orang (26\%). Hal ini memberikan penjelasan bahwa konsumen pengunjung Domino's Pizza Lippo Karawaci Utara adalah kalangan orang yang sudah bekerja di sektor swasta merupakan konsumen yang potensial pada produk makanan dan minuman. 


\section{Profil Responden Berdasarkan Penghasilan}

\begin{tabular}{|c|c|c|}
\hline \multicolumn{2}{|c}{ Tabel 7. Profil Responden Berdasarkan Penghasilan } \\
\cline { 2 - 3 } Tingkat Usia & Frekuensi & Presentase (\%) \\
\hline$<$ Rp1.000.000 & 15 & 15,46 \\
\hline $\begin{array}{c}\text { Rp1.000.001 - } \\
\text { Rp2.000.000 }\end{array}$ & 16 & 16,50 \\
\hline $\begin{array}{c}\text { Rp2.000.001 - } \\
\text { Rp4.000.000 }\end{array}$ & 34 & 35,05 \\
\hline >Rp4.000.001 & 32 & 32,99 \\
\hline Total & 97 & 100 \\
\hline
\end{tabular}

Tabel 7 menunjukkan bahwa penghasilan atau pendapatan paling tinggi dari responden adalah Rp2.000.001-Rp4.000.000 yaitu berjumlah 34 orang (35,05\%), kemudian diikuti oleh responden dengan penghasilan $>$ Rp4.000.001 yaitu berjumlah 32 orang $(32,99 \%)$. Hal ini menjelaskan bahwa seseorang yang memiliki kemampuan finansial yang lebih akan memungkinkan rutin untuk mencari pemenuh kepuasaan akan makanan dan minuman.

\section{Profil Responden Berdasarkan Domisili}

\begin{tabular}{|c|c|c|}
\hline \multirow{2}{*}{ Tabel 8. Profil Responden Berdasarkan Domisili } \\
\cline { 2 - 3 } Tingkat Usia & Frekuensi & Presentase (\%) \\
\hline Jakarta & 3 & 3,09 \\
\hline Bogor & 1 & 1,03 \\
\hline Depok & - & - \\
\hline Tangerang & 91 & 93,81 \\
\hline Bekasi & - & - \\
\hline Lainnya & 2 & 2,07 \\
\hline Total & 97 & 100 \\
\hline
\end{tabular}

Tabel 8 terlihat bahwa responden sebagaian besar berasal dari Tangerang yaitu berjumlah 91 orang $(93,81 \%)$, diikuti oleh responden yang berasal dari Jakarta sebanyak 3 orang (3,09\%). Hal ini memberikan penjelasaan bahwa pengunjung Domino's Pizza Lippo Karawaci Utara adalah yang tinggal di Tangerang dikarenakan dekat dengan lokasi restoran.

\section{Deskripsi Variabel}

\begin{tabular}{|c|c|c|c|c|c|c|}
\hline No & Pertanyaan & $\mathbf{N}$ & Min & Max & Mean & Ket \\
\hline 1 & $\begin{array}{l}\text { Domino's Pizza adalah } \\
\text { merek yang mudah } \\
\text { diingat }\end{array}$ & 97 & 1 & 5 & 4,51 & $\begin{array}{l}\text { Sangat } \\
\text { Setuju }\end{array}$ \\
\hline 2 & $\begin{array}{l}\text { Domino's Pizza } \\
\text { mempunyai logo yang } \\
\text { unik dan khas sehingga } \\
\text { mudah dikenali }\end{array}$ & 97 & 1 & 5 & 4,42 & Setuju \\
\hline 3 & $\begin{array}{l}\text { Citra perusahaan } \\
\text { Domino's Pizza } \\
\text { paling baik dibanding } \\
\text { perusahaan sejenisnya }\end{array}$ & 97 & 1 & 5 & 3,88 & Setuju \\
\hline 4 & $\begin{array}{l}\text { Domino's Pizza } \\
\text { merupakan restoran } \\
\text { cepat saji yang memiliki } \\
\text { layanan pesan antar yang } \\
\text { sangat baik }\end{array}$ & 97 & 1 & 5 & 4,06 & Setuju \\
\hline 5 & $\begin{array}{l}\text { Domino's Pizza adalah } \\
\text { perusahaan yang } \\
\text { berkompetensi tinggi }\end{array}$ & 97 & 1 & 5 & 4,11 & Setuju \\
\hline 6 & $\begin{array}{l}\text { Produk yang dimiliki } \\
\text { berkualitas dan } \\
\text { bervariasi }\end{array}$ & 97 & 1 & 5 & 4,28 & Setuju \\
\hline 7 & $\begin{array}{l}\text { Produk yang dijual } \\
\text { sesuai dengan yang } \\
\text { dipromosikan }\end{array}$ & 97 & 1 & 5 & 4,12 & Setuju \\
\hline 8 & $\begin{array}{l}\text { Harga yang ditawarkan } \\
\text { sesuai dengan kualitas } \\
\text { produk yang diberikan }\end{array}$ & 97 & 1 & 5 & 4,12 & Setuju \\
\hline 9 & $\begin{array}{l}\text { Produk yang ditawarkan } \\
\text { memiliki ciri khas }\end{array}$ & 97 & 1 & 5 & 4,19 & Setuju \\
\hline 10 & $\begin{array}{l}\text { Mengingat Domino's } \\
\text { Pizza ketika menyebut } \\
\text { kata Pizza }\end{array}$ & 97 & 1 & 5 & 3,81 & Setuju \\
\hline 11 & $\begin{array}{l}\text { Membeli produk } \\
\text { Domino's Pizza karena } \\
\text { mempunyai nama baik }\end{array}$ & 97 & 1 & 5 & 3,98 & Setuju \\
\hline 12 & $\begin{array}{l}\text { Merasa sangat puas } \\
\text { dengan produk yang } \\
\text { diberikan }\end{array}$ & 97 & 1 & 5 & 4,18 & Setuju \\
\hline 13 & $\begin{array}{l}\text { Domino's Pizza } \\
\text { memberikan cita rasa } \\
\text { produk yang lebih tinggi } \\
\text { dari para pesaingnya }\end{array}$ & 97 & 1 & 5 & 3,94 & Setuju \\
\hline 14 & $\begin{array}{l}\text { Pelayanan yang diberikan } \\
\text { sangat baik ketika } \\
\text { membeli produk di } \\
\text { Domino's Pizza Lippo } \\
\text { Karawaci Utara }\end{array}$ & 97 & 1 & 5 & 4,28 & Setuju \\
\hline & Valid N (listwise) & 97 & & & & \\
\hline
\end{tabular}

Tabel 9 merupakan hasil jawaban responden pada variabel brand image, terlihat bahwa jawaban rata-rata dengan nilai terendah adalah 3,81 pada butir pertanyaan "mengingat Domino's Pizza ketika menyebut kata pizza”, Sedangkan rata-rata nilai tertinggi 4,51 terdapat pada butir pertanyaan "Domino's Pizza adalah merek yang mudah diingat". Dalam hal ini dapat disimpulkan bahwa Domino's Pizza Lippo Karawaci Utara memiliki citra korporat yang baik dengan menciptakan hal kenyamanan dan kebersihan. 


\begin{tabular}{|c|c|c|c|c|c|c|}
\hline No & Pertanyaan & N & Min & Max & Mean & Ket \\
\hline 1 & $\begin{array}{l}\text { Ketika ingin makan pizza, } \\
\text { Domino's Pizza menjadi } \\
\text { tujuan utama }\end{array}$ & 97 & 1 & 5 & 3,77 & Setuju \\
\hline 2 & $\begin{array}{l}\text { Saya mengunjungi } \\
\text { Domino's Pizza Lippo } \\
\text { Karawaci Utara untuk } \\
\text { memenuhi kebutuhan } \\
\text { hidup makanan dan } \\
\text { minuman }\end{array}$ & 97 & 1 & 5 & 3,67 & Setuju \\
\hline 3 & $\begin{array}{l}\text { Saya memutuskan untuk } \\
\text { membeli Domino's Pizza } \\
\text { karena tertarik dengan } \\
\text { promosi yang diberikan } \\
\text { Domino's Pizza }\end{array}$ & 97 & 1 & 5 & 4,13 & Setuju \\
\hline 4 & $\begin{array}{l}\text { Saya mendapatkan } \\
\text { informasi mengenai } \\
\text { Domino's Pizza melalui } \\
\text { kerabat (keluarga, teman) }\end{array}$ & 97 & 1 & 5 & 3,71 & Setuju \\
\hline 5 & $\begin{array}{l}\text { Saya mencari informasi } \\
\text { promosi Domino's Pizza } \\
\text { melalui media sosial } \\
\text { (instagram) }\end{array}$ & 97 & 1 & 5 & 3,65 & Setuju \\
\hline 6 & $\begin{array}{l}\text { Saya mencari informasi } \\
\text { produk Domino's Pizza } \\
\text { melalui website Domino's } \\
\text { Pizza Indonesia }\end{array}$ & 97 & 1 & 5 & 3,65 & Setuju \\
\hline 7 & $\begin{array}{l}\text { Sebelum saya } \\
\text { menentukan produk } \\
\text { makanan dan minuman } \\
\text { yang akan dibeli selalu } \\
\text { melihat merek dari } \\
\text { produk tersebut }\end{array}$ & 97 & 1 & 5 & 4,14 & Setuju \\
\hline 8 & $\begin{array}{l}\text { Saya mempertimbangkan } \\
\text { citra dari restoran ketika } \\
\text { memutuskan untuk } \\
\text { membelinya }\end{array}$ & 97 & 1 & 5 & 4,24 & Setuju \\
\hline 9 & $\begin{array}{l}\text { Saya memilih produk } \\
\text { merek Domino's Pizza } \\
\text { karena kualitas sudah } \\
\text { teruji }\end{array}$ & 97 & 1 & 5 & 4,13 & Setuju \\
\hline 10 & $\begin{array}{l}\text { Domino's Pizza menjual } \\
\text { produk yang beragam } \\
\text { dengan cita rasa pilihan }\end{array}$ & 97 & 1 & 5 & 4,11 & Setuju \\
\hline 11 & $\begin{array}{l}\text { Saya memutuskan } \\
\text { membeli produk } \\
\text { Domino's Pizza karena } \\
\text { harga sesuai dengan } \\
\text { kualitas produk }\end{array}$ & 97 & 1 & 5 & 4,13 & Setuju \\
\hline 12 & $\begin{array}{l}\text { Saya memutuskan untuk } \\
\text { membeli Domino's } \\
\text { Pizza karena produk } \\
\text { yang ditawarkan sesuai } \\
\text { dengan kebutuhan }\end{array}$ & 97 & 1 & 5 & 4,19 & Setuju \\
\hline 13 & $\begin{array}{l}\text { Saya merasa puas } \\
\text { membeli produk dari } \\
\text { Domino's Pizza Lippo } \\
\text { Karawaci Utara }\end{array}$ & 97 & 1 & 5 & 4,27 & Setuju \\
\hline 14 & $\begin{array}{l}\text { Saya akan } \\
\text { merekomendasikan } \\
\text { produk Domino's Pizza } \\
\text { kepada teman / keluarga }\end{array}$ & 97 & 1 & 5 & 4,21 & Setuju \\
\hline 15 & $\begin{array}{l}\text { Saya akan membeli } \\
\text { kembali produk dari } \\
\text { Domino's Pizza Lippo } \\
\text { Karawaci Utara }\end{array}$ & 97 & 1 & 5 & 4,26 & Setuju \\
\hline & Valid N (listwise) & 97 & & & & \\
\hline
\end{tabular}

Pada tabel 10, diperoleh hasil jawaban responden variabel keputusan pembelian, terlihat bahwa jawaban rata-rata nilai terendah 3,65 pada butir pertanyaan "Saya mencari informasi promosi Domino's Pizza melalui media sosial (instagram)" dan "Saya mencari informasi produk Domino's Pizza melalui website Domino's Pizza Indonesia”. Sedangkan nilai rata-rata tertinggi 4,27 terdapat pada pertanyaan "Saya merasa puas membeli produk dari Domino's Pizza Lippo Karawaci Utara". Dalam hal ini dapat disimpulkan bahwa Domino's Pizza Lippo Karawaci Utara memiliki kualitas produk yang baik.

\section{Uji Validitas dan Uji Reliabilitas Uji Validitas}

Pengujian validitas instrumen diperoleh dari hasil uji instrumen terhadap 30 responden awal. Uji validitas dilakukan dengan mengkolerasikan skor yang diperoleh dari setiap butir pertanyaan dengan skor total untuk setiap variabel.

\section{Tabel 11. Hasil Pengujian Validitas Variabel Brand Image}

\begin{tabular}{|c|l|c|c|c|}
\hline No & \multicolumn{1}{|c|}{ Pertanyaan } & $\mathbf{r}_{\text {hitung }}$ & $\mathbf{r}_{\text {tabel }}$ & Ket \\
\hline 1 & $\begin{array}{l}\text { Domino's Pizza adalah merek yang } \\
\text { mudah diingat }\end{array}$ & 0,692 & 0,361 & Valid \\
\hline 2 & $\begin{array}{l}\text { Domino's Pizza mempunyai logo } \\
\text { yang unik dan khas sehingga mudah } \\
\text { dikenali }\end{array}$ & 0,776 & 0,361 & Valid \\
\hline 3 & $\begin{array}{l}\text { Citra perusahaan Domino's Pizza } \\
\text { paling baik dibanding perusahaan } \\
\text { sejenisnya }\end{array}$ & 0,617 & 0,361 & Valid \\
\hline 4 & $\begin{array}{l}\text { Domino's Pizza merupakan restoran } \\
\text { cepat saji yang memiliki layanan } \\
\text { pesan antar yang sangat baik }\end{array}$ & 0,566 & 0,361 & Valid \\
\hline 5 & $\begin{array}{l}\text { Domino's Pizza adalah perusahaan } \\
\text { yang berkompetensi tinggi }\end{array}$ & 0,301 & 0,361 & Tidak \\
\hline 6 & $\begin{array}{l}\text { Produk yang dimiliki berkualitas dan } \\
\text { bervariasi }\end{array}$ & 0,627 & 0,361 & Valid \\
\hline 7 & $\begin{array}{l}\text { Produk yang dijual sesuai dengan } \\
\text { yang dipromosikan }\end{array}$ & 0,807 & 0,361 & Valid \\
\hline 8 & $\begin{array}{l}\text { Harga yang ditawarkan sesuai dengan } \\
\text { kualitas produk yang diberikan }\end{array}$ & 0,637 & 0,361 & Valid \\
\hline 9 & $\begin{array}{l}\text { Produk yang ditawarkan memiliki } \\
\text { ciri khas }\end{array}$ & 0,627 & 0,361 & Valid \\
\hline 10 & $\begin{array}{l}\text { Mengingat Domino's Pizza ketika } \\
\text { menyebut kata Pizza }\end{array}$ & 0,532 & 0,361 & Valid \\
\hline 11 & $\begin{array}{l}\text { Membeli produk Domino's Pizza } \\
\text { karena mempunyai nama baik }\end{array}$ & $\begin{array}{l}\text { Domino's Pizza adalah merek yang } \\
\text { mudah diingat }\end{array}$ & $\begin{array}{l}\text { ketayanan yang diberikan sangat baik } \\
\text { Pizza membeli produk di Domino's }\end{array}$ \\
\hline 12 & $\begin{array}{l}\text { Merasa sangat puas dengan produk } \\
\text { yang diberikan }\end{array}$ & $0,727,361$ & Valid \\
\hline $\begin{array}{l}\text { pomino's Pizza memberikan cita rasa } \\
\text { pesaingnya }\end{array}$ & 0,726 & 0,361 & Valid \\
\hline
\end{tabular}


Hasil pada Tabel 11 menunjukkan bahwa terdapat 1 butir pertanyaan mengenai brand image (X) yang tidak valid dikarenakan hasil $\mathrm{r}_{\text {hitung }}<$ dari $\mathrm{r}_{\text {tabel }}$ Untuk 14 butir pertanyaan lainnya dikatakan valid dikarenakan hasil $\mathrm{r}_{\text {hitung }}>$ dari $\mathrm{r}_{\text {tabel }}$ Artinya terdapat 1 butir pertanyaan yang tidak dapat digunakan dan 14 butir lainnya dapat digunakan pada instrumen penelitian utama.

\begin{tabular}{|c|c|c|c|c|}
\hline No & Pertanyaan & $r_{\text {hitung }}$ & $r_{\text {tabel }}$ & Ket \\
\hline 1 & $\begin{array}{l}\text { Ketika ingin makan pizza, Domino's } \\
\text { Pizza menjadi tujuan utama }\end{array}$ & 0,545 & 0,361 & Valid \\
\hline 2 & $\begin{array}{l}\text { Saya mengunjungi Domino's } \\
\text { Pizza Lippo Karawaci Utara untuk } \\
\text { memenuhi kebutuhan hidup makanan } \\
\text { dan minuman }\end{array}$ & 0,682 & 0,361 & Valid \\
\hline 3 & $\begin{array}{l}\text { Saya memutuskan untuk membeli } \\
\text { Domino's Pizza karena tertarik } \\
\text { dengan promosi yang diberikan } \\
\text { Domino's Pizza }\end{array}$ & 0,726 & 0,361 & Valid \\
\hline 4 & $\begin{array}{l}\text { Saya mendapatkan informasi } \\
\text { mengenai Domino's Pizza melalui } \\
\text { kerabat (keluarga, teman) }\end{array}$ & 0,443 & 0,361 & Valid \\
\hline 5 & $\begin{array}{l}\text { Saya mencari informasi promosi } \\
\text { Domino's Pizza melalui media sosial } \\
\text { (instagram) }\end{array}$ & 0,600 & 0,361 & Valid \\
\hline 6 & $\begin{array}{l}\text { Saya mencari informasi produk } \\
\text { Domino's Pizza melalui website } \\
\text { Domino's Pizza Indonesia }\end{array}$ & 0,447 & 0,361 & Valid \\
\hline 7 & $\begin{array}{l}\text { Sebelum saya menentukan produk } \\
\text { makanan dan minuman yang akan } \\
\text { dibeli selalu melihat merek dari } \\
\text { produk tersebut }\end{array}$ & 0,779 & 0,361 & Valid \\
\hline 8 & $\begin{array}{l}\text { Saya mempertimbangkan citra dari } \\
\text { restoran ketika memutuskan untuk } \\
\text { membelinya }\end{array}$ & 0,641 & 0,361 & Valid \\
\hline 9 & $\begin{array}{l}\text { Saya memilih produk merek Domino's } \\
\text { Pizza karena kualitas sudah teruji }\end{array}$ & 0,758 & 0,361 & Valid \\
\hline 10 & $\begin{array}{l}\text { Domino's Pizza menjual produk yang } \\
\text { beragam dengan cita rasa pilihan }\end{array}$ & 0,731 & 0,361 & Valid \\
\hline 11 & $\begin{array}{l}\text { Saya memutuskan membeli produk } \\
\text { Domino's Pizza karena harga sesuai } \\
\text { dengan kualitas produk }\end{array}$ & 0,810 & 0,361 & Valid \\
\hline 12 & $\begin{array}{l}\text { Saya memutuskan untuk membeli } \\
\text { Domino's Pizza karena produk yang } \\
\text { ditawarkan sesuai dengan kebutuhan }\end{array}$ & 0,846 & 0,361 & Valid \\
\hline 13 & $\begin{array}{l}\text { Saya merasa puas membeli produk } \\
\text { dari Domino's Pizza Lippo Karawaci } \\
\text { Utara }\end{array}$ & 0,862 & 0,361 & Valid \\
\hline 14 & $\begin{array}{l}\text { Saya akan merekomendasikan produk } \\
\text { Domino's Pizza kepada teman / } \\
\text { keluarga }\end{array}$ & 0,787 & 0,361 & Valid \\
\hline 15 & $\begin{array}{l}\text { Saya akan membeli kembali produk } \\
\text { dari Domino's Pizza Lippo Karawaci } \\
\text { Utara }\end{array}$ & 0,789 & 0,361 & Valid \\
\hline
\end{tabular}

Hasil di tabel 12 menunjukkan bahwa semua butir pertanyaan mengenai keputusan pembelian (Y) yang sebanyak 15 butir pertanyaan adalah valid. Karena menunjukkan hasil $\mathrm{r}_{\text {hitung }}$ lebih besar dari $\mathrm{r}_{\text {tabel }}$ artinya semua butir pertanyaan dapat digunakan sebagai instrumen penelitian.

\section{Uji Reliabilitas}

Tabel 13. Hasil Uji Reliabilitas Variabel Brand Image

\begin{tabular}{|c|c|c|}
\hline Cronbach's Alpha & $\begin{array}{c}\text { Cronbach'sAlpha Based } \\
\text { on Standardized Items }\end{array}$ & N of Items \\
\hline, 749 & .914 & 16 \\
\hline
\end{tabular}

Variabel yang reliabel dalam suatu penelitian yaitu apabila nilai Cronbach Alpha 0,60. Berdasarkan hasil tabel 13 menunjukkan bahwa nilai Cronbach Alpha variabel X adalah 0,749. Dapat disimpulkan bahwa instrumen brand image yang disusun adalah reliabel, sehingga menunjukkan kehandalan kuesioner yang digunakan dalam penelitian ini.

\begin{tabular}{|c|c|c|}
\hline \multicolumn{2}{|c|}{ Tabel 14. Hasil Uji Reliabilitas Variabel Keputusan Pembelian } \\
\hline Cronbach's Alpha & $\begin{array}{c}\text { Cronbach'sAlpha Based } \\
\text { on Standardized Items }\end{array}$ & N of Items \\
\hline .761 & .937 & 16 \\
\hline
\end{tabular}

Berdasarkan hasil tabel 14 menunjukkan bahwa nilai Cronbach Alpha variabel Y adalah 0,761. Dapat disimpulkan bahwa instrumen keputusan pembelian yang disusun adalah reliabel, sehingga menunjukkan bahwa kuesioner yang digunakan dalam penelitian ini merupakan kuesioner yang handal.

\section{Uji Normalitas}

Uji normalitas berfungsi untuk mengetahui apakah variabel dependen dan variabel independen memiliki distribusi normal atau tidak dalam sebuah model regresi. Model regresi yang baik adalah yang berdistribusi normal atau mendekati normal. Uji normalitas menggunakan uji One Sample Kolmogorof-Smirnov.

\begin{tabular}{l}
\hline \multicolumn{2}{|c}{ Tabel 15. Hasil Uji Normalitas } \\
\begin{tabular}{|l|l|r|}
\hline \multicolumn{2}{|c|}{} & $\begin{array}{c}\text { Unstandardized } \\
\text { Residual }\end{array}$ \\
\hline N & 97 \\
\hline Normal Parameters ${ }^{\mathrm{a}, \mathrm{b}}$ & Mean & $0 \mathrm{E}-7$ \\
\cline { 2 - 3 } & Std. Deviation & 4,71461671 \\
\hline Most Extreme Differences & Absolute &, 077 \\
\cline { 2 - 3 } & Positive &, 053 \\
\cline { 2 - 3 } & Negative &,- 077 \\
\hline Kolmogorov-Smirnov Z &, 755 \\
\hline Asymp. Sig. (2-tailed) &, 618 \\
\hline 1. Test distribution is Normal. & \\
\hline 2. Calculated from data. & \multicolumn{2}{|}{} \\
\hline
\end{tabular}
\end{tabular}


Tabel 15 menunjukkan hasil uji normalitas dengan uji One Sample Kolmogorov-Smirnov diperoleh nilai Asymp.sig. sebesar 0,618>0,05, sehingga dapat disimpulkan bahwa data penelitian yang digunakan berdistribusi normal.

\section{Uji Koefisien Korelasi}

Uji koefisien korelasi digunakan untuk mengetahui tingkat hubungan antara variabel bebas dan terikat yang ditunjukkan dengan koefisien korelasi. Hasil pengujian koefisien korelasi dapat dilihat pada tabel 16.

\begin{tabular}{|l|l|c|c|}
\hline \multicolumn{4}{|c}{ Tabel 16. Hasil Uji Koefisien Korelasi } \\
\hline \multirow{4}{*}{ Brand Image } & Pearson Correlation & 1 &, $688^{* *}$ \\
\cline { 2 - 4 } & Sig. (2-tailed) & &, 000 \\
\cline { 2 - 4 } & $\mathrm{N}$ & 97 & 97 \\
\hline \multirow{2}{*}{$\begin{array}{l}\text { Keputusan } \\
\text { Pembelian }\end{array}$} & Pearson Correlation &, $688^{* *}$ & 1 \\
\cline { 2 - 4 } & Sig. (2-tailed) &, 000 & \\
\cline { 2 - 4 } & $\mathrm{N}$ & 97 & 97 \\
\hline **. Correlation is significant at the 0.01 level (2-tailed). & \\
\hline
\end{tabular}

Berdasarkan hasil tabel 16 dengan responden berjumlah 97 diperoleh nilai korelasi sebesar 0,688 . Oleh karena itu dapat disimpulkan terdapat hubungan yang kuat antara variabel brand image dengan variabel keputusan pembelian. Hal ini dapat diartikan bahwa brand image Domino's Pizza mendapatkan citra yang baik dimata masyarakat. Domino's Pizza dianggap sebagai brand yang baik dibandingkan brand lainnya. Dalam hal keputusan pembelian produk di Domino's Pizza Lippo Karawaci Utara responden mempunyai persepsi yang baik terhadap brand dan promo yang ditawarkan sesuai dengan produk yang disajikan membuat konsumen puas terhadap keputusan pembelian di Domino's Pizza Lippo Karawaci Utara.

\section{Uji Koefisien Determinasi}

Koefisien determinasi $\left(\mathrm{R}^{2}\right)$ digunakan untuk mengetahui besarnya (persentase) perubahan variabel terikat $(\mathrm{Y})$ yang dipengaruhi variabel bebas (X). Pada uji SPSS, nilai koefisien determinasi ditentukan dengan nilai adjusted $R$ square.

\begin{tabular}{|c|c|c|c|c|}
\hline \multicolumn{7}{|c|}{ Tabel 17. Koefisien Determinasi } \\
\hline Model & R & R Square & $\begin{array}{c}\text { Adjusted } \\
\text { R Square }\end{array}$ & $\begin{array}{c}\text { Std. Error of } \\
\text { the Estimate }\end{array}$ \\
\hline 1 &, $688^{\text {a }}$ &, 473 &, 468 & 4,73937 \\
\hline $\begin{array}{l}|c| \\
\text { a. Predictors: (Constant), Brand Image } \\
\text { b. Dependent Variable: Keputusan Pembelian }\end{array}$ \\
\hline
\end{tabular}

Hasil analisis data pada Tabel 17 diketahui nilai koefisien determinasi ( $R$ Square) adalah 0,473, yang berarti $47,3 \%$ keputusan pembelian di Domino's Pizza dipengaruhi oleh brand image restoran tersebut, sedangkan sisanya $52,7 \%$ dipengaruhi oleh variabel-variabel lain di luar penelitian, seperti loyalitas pelanggan, kualitas pelayanan, dan lain sebagainnya. Nilai tersebut diartikan bahwa brand image cukup mempengaruhi keputusan pembelian konsumen Domino's Pizza Lippo Karawaci Utara. Walaupun banyak penilaian terhadap harga yang ditawarkan cukup mahal, namun konsumen merasa puas terhadap produk yang ditawarkan. Dengan brand image yang bagus yang dimiliki Domino's Pizza tersebut maka akan meningkatkan keputusan pembelian konsumen.

\section{Uji Regresi Linear Sederhana}

Uji regresi linier sederhana berfungsi untuk menganalisis hubungan dan linier brand image terhadap keputusan pembelian di Domino's Pizza Lippo Karawaci Utara.

\begin{tabular}{|c|c|c|c|c|c|c|}
\hline \multicolumn{7}{|c|}{ Tabel 18. Koefisien Regresi Sederhana } \\
\hline \multicolumn{7}{|c|}{ Coefficients ${ }^{a}$} \\
\hline \multirow{2}{*}{\multicolumn{2}{|c|}{ Model }} & \multicolumn{2}{|c|}{$\begin{array}{l}\text { Unstandardized } \\
\text { Coefficients }\end{array}$} & \multicolumn{3}{|c|}{ Standardized Coefficients } \\
\hline & & B & $\begin{array}{l}\text { Std. } \\
\text { Error }\end{array}$ & Beta & $t$ & Sig. \\
\hline \multirow{2}{*}{1} & (Constant) & 13,951 & 5,073 & & 2,750 &, 007 \\
\hline & Brand Image & 802 & ,087 & ,688 & 9,239 & ,000 \\
\hline
\end{tabular}

Hasil perhitungan koefisien regresi sederhana pada tabel 18 diketahui nilai koefisien konstanta adalah 13.951, sedangkan koefisien variabel bebas $(\mathrm{X})$ adalah sebesar 0,802 . Sehingga persamaan regresi dalam penelitian ini adalah $\mathrm{Y}=13,951+0,802 \mathrm{X}$.

Nilai konstanta 13,951, menyatakan bahwa jika nilai brand image 0, maka keputusan pem- 
belian memiliki nilai 13,951. Nilai koefisien variabel bebas 0,802 diartikan bahwa terdapat hubungan yang searah antara variabel brand image dengan variabel terikatnya keputusan pembelian, setiap kenaikan satu satuan variabel brand image akan menyebabkan kenaikan keputusan pembelian 0,802 .

\section{Uji Hipotesis (Uji t)}

Uji t digunakan untuk menguji secara parsial signifikansi hubungan antar variabel $\mathrm{X}$ dan $\mathrm{Y}$, dalam penelitian ini apakah variabel brand image memiliki pengaruh terhadap variabel keputusan pembelian.

\begin{tabular}{|c|c|c|c|c|c|c|}
\hline \multicolumn{7}{|c|}{$\begin{array}{l}\text { Tabel 19. Hasil Uji Koefisie } \\
\text { Coefficients }\end{array}$} \\
\hline \multirow{2}{*}{\multicolumn{2}{|c|}{ Model }} & \multicolumn{2}{|c|}{$\begin{array}{c}\text { Unstandardized } \\
\text { Coefficients }\end{array}$} & \multicolumn{3}{|c|}{ Standardized Coefficients } \\
\hline & & B & $\begin{array}{l}\text { Std. } \\
\text { Error }\end{array}$ & Beta & $t$ & Sig. \\
\hline \multirow{2}{*}{1} & (Constant) & 13,951 & 5,073 & & 2,750 &, 007 \\
\hline & Brand Image & .802 & ,087 & ,688 & 9,239 &, 000 \\
\hline
\end{tabular}

Tabel 19 merupakan hasil uji pengaruh variabel brand image secara parsial terhadap keputusan pembelian di Domino's Pizza Lippo Karawaci Utara, dari hasil yang didapatkan diketahui nilai $\mathrm{t}_{\text {hitung }}$ 9,239 dengan signifikansi 0,000. Nilai tabel $\mathrm{t}$ diperoleh 1,98525 dengan tingkat signifikansi yang ditentukan 0,05. Dari hasil tersebut terlihat nilai $\mathrm{t}_{\text {hitung }}>\mathrm{t}_{\text {tabel }}(9,239>1,98525)$ dan nilai signifikansi $0,000<0,05$, sehingga dapat disimpulkan bahwa brand image memiliki pengaruh positif dan signifikan terhadap keputusan pembelian di Dominos's Pizza Lippo Karawaci Utara.

\section{Pembahasan}

Dari hasil uji koeefisien korelasi, diperoleh nilai korelasi sebesar 0,688, yang menunjukkan terdapat hubungan yang kuat antara variabel brand image dengan variabel keputusan pembelian. Pada tabel Hasil Output Regresi Linier pada Model Summary, Nilai koefisien determinasi ( $R$ Square) sebesar 0,473 atau 47,3\%, yang menunjukkan bahwa variabel Keputusan Pembelian dipengaruhi oleh variabel brand image sebesar $47,3 \%$, sisanya $52,7 \%$ dipengaruhi oleh variabel lain yang tidak diujikan dalam penelitian ini.

Pada Tabel Coefficients model 1 brand image, dihasilkan nilai Sig. 0,000 yang lebih kecil dari nilai probabilitas $0,05($ Sig. $0,000<0,05)$, serta nilai $t_{\text {hitung }}$ $(9,239)>t_{\text {tabel }}(1,985)$ dengan taraf signifikansi 5 , hal ini menyatakan bahwa brand image memiliki pengaruh yang positif dan signifikan terhadap Keputusan Pembelian.

Hasil perhitungan koefisien regresi sederhana diperoleh Keputusan Pembelian $=13,951+0,802$ brand image. Nilai koefisien variabel brand image 0,802 diartikan setiap kenaikan satu satuan variabel brand image akan menyebabkan kenaikan keputusan pembelian 0,802.

Berdasarkan teori dan hasil penelitian secara statistik menunjukkan terdapat penerimaan Hipotesis $\mathrm{H}_{\mathrm{a}}$ sehingga dapat dibuktikan bahwa brand image berpengaruh positif dan signifikan terhadap keputusan pembelian di Dominos's Pizza Lippo Karawaci Utara. Hal ini menunjukkan bahwa semakin baik brand image yang dimiliki, maka semakin tinggi pula keputusan pembelian konsumen, juga sebaliknya, semakin tidak baiknya brand image yang ditimbulkan, menyebabkan semakin rendah keputusan pembelian yang dihasilkan.

\section{SIMPULAN}

Dari hasil analisis data diperoleh nilai $\mathrm{t}_{\text {hitung }}$ $>\mathrm{t}_{\text {tabel }}(9,239>1,98525)$ dan nilai signifikansi $0,000<0,05$, dapat disimpulkan bahwa brand image memiliki pengaruh positif dan signifikan terhadap keputusan pembelian di Dominos's Pizza Lippo Karawaci Utara.

Besarnya kontribusi brand image yang mempengaruhi keputusan pembelian adalah 47,3\% (dengan nilai $R$ Square $=0,473$ ), sedangkan sisanya $52,7 \%$ dipengaruhi oleh variabel-variabel lain diluar penelitian, seperti pengaruh loyalitas pelanggan, kualitas pelayanan, dan lain sebagainya.

\section{DAFTAR PUSTAKA}

Aaker, D.A. (2011). Managing Brand Equity: Capitalizing on the Value of Brand Name. New York: The Free Press. 
Aaker, D. A., Kumar, V., \& Day, G. (2010). Marketing Research 9 Edition. Jhon Wiley \& Sons, Davers.

Abdullah, A. (2015). Perceived Quality, Brand Image, and Brand Trust as Determinants of Brand Loyalty. Journal of Research in Business and Management, Vol.3 No.4.,Page 01-08.

Alsa, A. (2007). Pendekatan Kuantitatif dan Kualitatif, Serta kombinasinya Dalam Penelitian Psikologi. Yogyakarta: Pustaka Pelajar.

Bastian, D.A. (2014). Analisa Penagruh Citra Merek (Brand Image) dan Kepercayaan Merek (Brand Trust) terhadap Loyaltias Merek (Brand Loyalty) Ades PT Alfindo Putra Setia. Jurnal Manajemen Pemasaran Petra, Voume 2(N0.1) 1-9.

Ghozali, I. (2011). Aplikasi Analisis Multivariate dengan Program IBM SPSS 20. Semarang: Bina Pustaka.

Ghozali, I. (2017). Aplikasi Analisis Multivariate dengan Program SPSS. Semarang: Penerbit Universitas Diponogoro.

Hamdi, A.S. (2014). Metode Penelitian Kuantitatif Aplikasi dalam Pendidikan. Yogyakarta : Deepublish.

Hangestu, N. \& Iskandar, D.A. (2017). Pengaruh Citra Merek Dan Harga Terhadap Loyalitas Pelanggan Air Minum Dalam Kemasan. Jurnal Riset Manajemen Dan Bisnis (JRMB) Fakultas Ekonomi UNIAT, Volume 2 (No.3).

Keller, L. (2012). How to Manage Brand Equity. Jakarta: Gramedia Pustaka.

Kotler, \& Amstrong. (2008). Prinsip-Prinsip Pemasaran. Jakarta: Erlangga.

Kotler, P., \& Kevin, L. K. (2012). Marketing Management 14th Edition. New Jersey : Prentice Hall.

Kurnaiwan, R. A.J., \& Adriana, A. (2017). Pengaruh Brand Image Terhadap Kepuasan Konsumen Pada Restoran Kfc Di Surabaya. Program Manajemen Perhotelan Program Studi Manajemen Fakultas Ekonomi Universitas Kristen Petra http://publication.petra.ac.id/ index.php/manajemen-perhotelan/article/ download/6406/5825.

Nurjannah, F. A., \& Egi, A. (2018). Citra Merek
Serta keputusan Pembelian pada Cafe Warunk Upnormal. Jurnal Dimensi Vol 7, No 1 : 3658, Maret 2018. http://dx.doi.org/10.33373/ dms.v7i1.1632.

Pantri, H. S. (2015). Analisis Pengaruh Brand Image dan Kualitas Produk terhadap Keputusan Pembeliaan Konsumen pada Hanphone Nexian. Binus Bussines School, Journal of economics and business Volume 4(2),171-205.

Rizan, M., Handayani K. L., \& Kresnamurti A. (2015). Pengaruh Citra Merek dan Kualitas Produk Terhadap Keputusan Pembelian (Studi Banding Konsumen Indomie dan Mie Sedaap). Jurnal Riset Manajemen Sains Indonesia (JRMSI). Fakultas Ekonomi Universitas Negeri Jakarta.

Schiffman, \& Kanuk. (2008). Perilaku Konsumen Edisi 7. Jakarta: PT. Indeks Gramedia.

Sedarmayanti, \& Hidayat, S. (2011). Metodologi Penelitian. Bandung : Mandar Maju.

Setiadi, N.J. (2003). Perilaku Konsumen: Konsep dan Implikasi untuk Strategi dan Penelitian Pemasaran. Jakarta: Prenada Media.

Simmora, H. (2011). Manajemen Sumber Daya Manusia. Jakarta: PT. Bumi Aksara.

Simamora, H. (2014). Manajemen Sumber Daya Manusia. Yogyakarta: Bagian Penerbitan Sekolah Tinggi YKPN.

Sinaga, R. (2017). Pengaruh Brand Image terhadap Keputusan pembelian pada Cocorico Fafe \& Resto Bandung. e-Proceeding of Applied Science : Vol.3, No.2 Agustus 2017, Page 258264.

Sugiyono. (2014). Metode Penelitian Pendidikan Pendekatan Kuantitatif, Kualitatif, dan R\&D. Bandung: Alfabeta.

Surachman, S.A. (2008). Dasar-Dasar Manajemen Merek. Malang: Banyumedia Publish.

Suyanto, M. 2007. Marketing Strategy Top Brand Indonesia. Yogyakarta: Andi Offset.

Tjiptono, F. (2015). Strategi Pemasaran Edisi 4. Yogyakarta : Andi Offset.

Top Brand Award (2018). Top Brand Index Fase 22018 Kategori Restoran Pizza. https://www. topbrand-award.com/top-brand-index/?tbi_ find=pizza. 